\title{
THE CLASSICAL ASSOCIATION OF SOUTH AFRICA: APRIL 1956-JANUARY 1961
}

\author{
W J Henderson (University of Johannesburg)
}

\section{Introduction}

With the declining numbers of classical scholars at universities and Latin teachers at schools in South Africa, a direct consequence of the ever-shrinking pool of students of Greek and Latin at school and university, it seems to be increasingly necessary and indeed urgent to record the history of the main organisation that has promoted, nurtured and administered the cause of Classics in this country, the Classical Association of South Africa (CASA). In addition, the Association is approaching its $50^{\text {th }}$ year (1956-2006), which deserves to be celebrated. Such a history ought to document the activities, issues, decisions and events that shaped the association, but also pay tribute to the people who in all sorts of ways and to many varying degrees contributed to the origins and development of the association. That is the aim of this series of articles.

The material for this history has been gathered from the association's archive held in the Department of Greek and Latin Studies at the University of Johannesburg (formerly the Rand Afrikaans University). ${ }^{1}$ The archive material consists of (1) the documents generated by the Executive Committee in its administration of the Association; (2) the financial documents; (3) the general correspondence; and (4) membership lists. This account has been based almost entirely on (1), since this is where the functioning of the Association has its centre. ${ }^{2}$ Administrative correspondence between members of the Executive Committee is referred to by sender $(\mathrm{C}=$ Chairperson; $\mathrm{ST}=$ Secretary-Treasurer; $\mathrm{S}=$ Secretary; $\mathrm{T}=$ Treasurer; $\mathrm{EC}=$ Executive Committee) with the date. Other correspondence is identified by the name of the sender. Personal matters and opinions exchanged in confidence in the correspondence have been excluded. $^{3}$

1. For additional material on the history of Classics in South Africa, see Smuts (1960, 1966 and 1976); for surveys of Classical studies, see Matier (1986 and 1988) and Henderson (1989); for a list of work published by Classical scholars in South Africa, see Henderson (1986 and 1995).

2. Financial documents include receipts for payment, membership subscriptions and biennial reports; general correspondence includes letters and notes between members of the Executive, and between the Executive and other members of the Association. Some of the material is interesting (for us of more inflationary times, strangely low figures in monetary affairs; handwritten notes of scholars expressing personal views; first enrolment slips of members who were to play prominent roles in CASA), but it is by its very nature only the raw material upon which some of the decisions affecting the Association were made.

3. Some names have changed: in Zimbabwe (formerly Rhodesia), Salisbury is now Harare and the University College of Rhodesia and Nyasaland is now the University of Zimbabwe; in South Africa, the Transvaal is now Gauteng and the University of the Orange Free State is now the University of the Free State. The Rand Afrikaans University became the University of Johannesburg on 1 January 2005. 


\section{First CASA conference, 4-7 April 1956, Pretoria}

\subsection{Conference proceedings}

The form of CASA as it exists today was established at this conference. ${ }^{4}$ A group of scholars had returned from study abroad after the Second World War, imbued with the desire to promote the cause of Classics in South Africa through research, teaching and regular conferences. At the opening meeting, the 17 delegates present ${ }^{5}$ elected an interim Executive Committee for the duration of the conference. This committee consisted of Prof. Gonin (Pretoria) in the Chair, Dr Lubbe (Pretoria) as Secretary, and Dr Naudé (Witwatersrand) as Treasurer. In addition, Proff. Haarhoff (Witwatersrand) and Petrie (Natal) were elected as Honorary Presidents.

The interim chairperson explained that only university teachers had been invited, since the primary need was, as a first step, to establish an association to promote research; expansion into the schools would develop from there. The meeting then formally established the Classical Association of South Africa, to be organised nationally and regionally. Two regions were to be formed: Northern (Universities of Pretoria, South Africa, Witwatersrand, Potchefstroom) and Southern (Universities of Cape Town and Stellenbosch), with the Universities of the Orange Free State and Natal and Rhodes University free to join either. The aim of the regional branches was involvement in the status and teaching of Latin (and to a lesser extent, Greek) at schools. The association was to meet annually on a rotation basis at the end of the summer vacation. Costs of travel and accommodation were to be shared pro rata from delegates' pooled donations. There were to be two categories of members: full members (university lecturers, teachers of Greek and/or Latin at school, and interested persons with Greek or Latin III) and Associate members (other interested persons). The new committee was to investigate the possibility of a publication for the association. It was decided to request the French Embassy in South Africa to arrange for Prof. Gonin to attend the FIEC conference in Avignon in September 1956 as the official representative of CASA. It was decided to compile a centralised catalogue of all books and periodicals on the Classics in South African libraries. The following Executive Committee was elected for 1957 and the next conference: Prof. Paap (Cape Town; Chair); Prof. Smuts (Stellenbosch; Secretary); and Prof. G P Goold (Cape Town; Treasurer). ${ }^{6}$ Nine papers were read, some of which were subsequently published in AClass 2 (1959). ${ }^{7}$

4. An earlier Classical Association of South Africa was in fact founded in March 1927 at Cape Town, but had virtually ceased to function by 1956. Among the founding members were the Hon. J H Hofmeyr, Proff. C S Edgar, W Rollo, A Petrie and T J Haarhoff; cf. Editors, AClass 1 (1958b) 164.

5. Proff. H L Gonin, A H R E Paap, P V Pistorius, W Postma, F Smuts; Drr. E L de Kock, W J G Lubbe, C P T Naudé, C A van Rooy, G van N Viljoen, O A von Weber; Messrs W N Coetzee, J H Grobler, A Lagouros, L J D La Grange, J P Louw and W J Richards. Prof. Haarhoff was abroad, but sent the following message: "Salvete, conlegae Societatis Classicae Africae Australis! Prospera faustaque eveniant disputationes vestrae classicae! Proficiant studia humaniora, vobis curantibus, in scholis atque universitatibus nostris omnibus! Me sane paenitet, rebus adstrictum domesticis, me ipsum adesse non posse; animo tamen me praesentem fingite omnia bona vobis precantem” ("Greetings, colleagues of the Classical Association of South Africa! Good luck with your classical discussions! May the humanities prosper, under your care, in all our schools and universities! I am truly sorry that, for domestic reasons, I cannot attend in person, but imagine me present in spirit wishing you all the best”).

6. Minutes of CASA foundation meeting, Room 30, New Arts Building, University of Pretoria, Wednesday, 4 April 1956, at 15:00.

7. Cf. further Editors, AClass 1 (1958b) 164-66. 
At the closing meeting on 4 April, attended by 14 delegates, ${ }^{8}$ the format of future conferences was set: a maximum of three papers per day; one hour to be allowed per paper, with 30-45 minutes for discussion; themes to be communicated to the Secretary one month prior to the conference; a regular session to be devoted to the teaching of Classics. The minutes of the meetings, together with a copy of the draft constitution, were to be sent to all university teachers of Classics. ${ }^{9}$ Delegates were to pay 10 shillings each towards the conference costs of £30.10. It was suggested that in future universities should be asked to contribute to at least the travel costs of their delegates. The Executive was to negotiate with the education authorities for the visit of a foreign scholar. ${ }^{10}$

\subsection{The Regional Branches}

The regional branches were to organise regular conferences in the two-year period between the national conferences. The Northern Regional Branch was formed on Saturday, 20 October 1956, at Potchefstroom. Ten members attended, and apologies were received from 16 others. The first committee elected consisted of Prof. Postma (Potchefstroom; Chair), Dr Naudé (Secretary-Treasurer), and Prof. Coetzee (Potchefstroom), Dr Lubbe and four others to be nominated to represent the universities of Pretoria, South Africa, Pietermaritzburg and Orange Free State. Among the proposals accepted were: that two meetings were to be held each year, with rotation of venue (that is, an AGM in October and a meeting for teachers early in the year); that membership of the association was to include membership of the regional branch; that, in view of the long distances some delegates had to travel, costs were to be shared on a pro rata basis (to be confirmed at national level); that recruitment among teachers was to be undertaken. ${ }^{11}$

The Southern Regional Branch, although not yet properly constituted, was already holding informal meetings at Stellenbosch and Cape Town.

In the meantime, the Johannesburg Classical Association, a survivor from the first Classical Association, had continued to thrive and celebrated its $30^{\text {th }}$ anniversary in 1955 . Many speakers gave talks, but the highlight was the annual Vergil Lecture delivered by the president, Prof. Haarhoff.

8. The presence at this meeting of Prof. Petrie, who had then already taught Classics at Natal for 46 years, was gratefully acknowledged by the Chairperson.

9. The basic provisions of the draft constitution had been drawn up by Van Rooy and Lubbe on board the Durban Castle sailing from the Netherlands to South Africa in July 1955 (note by Van Rooy on Durban Castle letterhead).

10. Minutes of Closing Meeting, Saturday, 7 April, at 10:45.

11. Minutes of the First Meeting of the Northern Branch, Saturday, 20 October 1956. 


\section{Second CASA conference, 12-15 February 1957, Stellenbosch}

\subsection{Conference proceedings}

Twenty-three delegates attended the second conference. ${ }^{12}$ The opening and closing meetings dealt with matters concerning the running of the association, inter alia the finalisation of the constitution, finances, the election of a committee to consult with the Suid-Afrikaanse Akademie on the spelling of Greek proper nouns in Afrikaans, and a proposal to start an exchange-scheme of museum items between South Africa and Italy. The financial support of the regional branches was formalised: branches were to receive $25 \%$ of the subscriptions paid for CASA membership, provided the branches were active and submitted annual reports to the central treasury. ${ }^{13}$ In his Annual Report, the Chairperson recorded the progress of the Association: the financial support of universities, the national catalogue of periodicals, the Avignon conference, and negotiations with the Netherlands-South Africa Cultural Exchange Programme for the Dutch scholar Prof. H Wagenvoort to visit South Africa. The most important decision was to publish the proceedings of the conference as Acta.

Seven papers were delivered, including one by a visitor from Holland, Dr W Luiks, and a report by Prof. Gonin on the conference of Latinists at Avignon in September 1956, where he had represented CASA. Another paper, by Prof. J P J van Rensburg (Stellenbosch), on the spelling of Classical proper nouns in Afrikaans, dealt with an issue that was to return many times and, in fact, is still a problem among Classicists writing in Afrikaans. In addition, for the first time a symposium was held on the teaching of Classics in South Africa. ${ }^{14}$ The Executive Committee was entrusted with the task of bringing this resolution to fruition. The members for next two years were Prof. Smuts (Chair), Prof. K D White (Rhodes; ViceChair), Dr Lubbe (Secretary-Treasurer) and, as Additional members, Prof. Viljoen (South Africa) and Dr Van Rooy (Orange Free State).

\subsection{Administration 1957-1959}

\subsubsection{General}

In the next two years the members of the Executive Committee conducted the affairs of the association (minutes, lists of members and schoolteachers, matters arising, proposals, payments to be made) by correspondence on typed foolscap-size paper with multiple carbon copies. ${ }^{15}$ The matter of an official letterhead and logo was debated, but initially correspondence bore only the name of the Association. In this way, several issues were dealt with. It was decided that any prominent person who was well disposed to the Classics and cultural values in general was eligible for election as an Honorary Member. To initiate the

12. Among those present was Prof. George Goold, who left South Africa for Canada on 20 September 1957; he then taught Classics at the Universities of Winnipeg, Toronto, Harvard, University College, London, and finally at Yale University, before becoming the illustrious Editor of the Loeb Greek Texts for over 25 years. He died on 5 December 2001. CASA gratefully acknowledges his contribution in its early years and honours his memory.

13. Cf. Minutes of Second Conference, Opening Meeting, 12 February; Closing Meeting, 15 February; Editors, AClass 1 (1958c) 170-73.

14. Cf. further Editors, AClass 1 (1958b) 166.

15. ST to C, 18 April 1957; C to ST, 6 May 1957; ST to C, 3 June 1957; ST to EC and White (English version), 5 November 1957. 
museum-exchange programme with Italy, Prof. White was asked to present a memorandum to the Museum Society for comment, and a sub-committee consisting of Classicists and others was elected, while the Chairperson was to investigate the matter during his sabbatical in Italy, January-June 1958.

\subsubsection{Date of the next conference}

At the Opening Meeting of the 1957 conference, provision was made in the constitution for a conference every two years. At the Closing Meeting, a proposal to hold the next conference in 1958 was ruled out of order. After the conference, a request for the earlier date was again made to the Executive Committee, on the grounds of the enthusiasm of delegates, the good publicity gained, and the large amount of business still to be finalised. However, the host department at the University of the Orange Free State was reluctant, suggesting a longer period for consolidation, growth in membership (especially among school teachers), the subcommittees to make progress, and administrative matters to be conducted without rush. The Executive Committee upheld the two-year provision of the constitution and confirmed the date as $1959 .^{16}$

The programme for the conference in Bloemfontein was finalised for 28-31 January, and arrangements for the accommodation and transport of delegates and for the official reception and excursion were made. On 5 November 1958, the Secretary-Treasurer gave notice in Afrikaans and English of the next conference to be held in Bloemfontein in late January 1959. Another notice dated 27 November 1958 invited delegates to offer papers and make the necessary arrangements for accommodation. A system of financing attendance was designed and served the association for many years. Senior delegates, who delivered papers and obtained funds from their universities, pooled their grants and reclaimed the equivalent of a second-class train ticket and accommodation, although most delegates were lodged with private families. In this way, costs were shared and the attendance of junior colleagues subsidised. The Transvaal Education Department gave teachers leave to attend the conference. $^{17}$

\subsubsection{The position of Classics}

In April 1957, as a matter of urgency, representations were made to the Ministers of Education (Mr J H Viljoen) and of Justice (Adv. C R Swart) to defend the position of Latin in the schools. ${ }^{18}$ Written and verbal guarantees of support were given, but this was destined to be an ever-present issue between CASA and the authorities. In May, Prof. Viljoen, alerted to an article in Die Kerkbode, expressed his concern that the introduction of an African language as a third language for matriculation would weaken the position of Latin, and suggested that the Secretary-Treasurer of CASA submit a reply to Die Kerkbode. ${ }^{19}$ Also in May, Prof. Van Rooy sent a circular to colleagues, requesting their response to a set of questions to provide material for Prof. $\mathrm{H}$ van der Merwe Scholtz, Rector of the University of the Orange Free State, who was to address the Suid-Afrikaanse Akademie van Wetenskap en

16. ST to EC, 5 November 1957; Van Rooy to ST, 25 November 1957; C to ST, 14 December 1957; ST to EC, 26 December 1957.

17. ST to TED, 23 January 1959; reply of TED 27 January 1959.

18. C to Ministers, undated; C to EC, 22 April 1957; ST to C, 3 June 1957; C to ST, 15 June 1957.

19. Viljoen to ST, 6 May 1958; ST to Viljoen, 4 June 1958. 
Kuns on the perceived deteriorating position of the humanities vis-à-vis the swift growth of science and technology. ${ }^{20}$ In June, presentations made to the Transvaal and Cape Synods of the Dutch Reformed Church to maintain Latin I for theological studies, failed. ${ }^{21}$ The SuidAfrikaanse Akademie formally welcomed co-operation with CASA through its Taalkommissie on the problem of the orthography of Greek proper nouns in Afrikaans. ${ }^{22}$ For the compilation of the list of relevant periodicals and works available in local libraries, the convener Prof. Viljoen sent a circular to each department, with provisional lists and the request to check and expand the contents. ${ }^{23}$

\subsubsection{Visit of Wagenvoort}

Arrangements were finalised for the visit of Prof. H Wagenvoort (Utrecht) to South Africa in 1957. He duly arrived in Cape Town by ship, and was met and placed on the train by Proff. Smuts and Paap. His itinerary (9 September-18 October) included visits to Cape Town, Pretoria, Johannesburg, Bloemfontein, Potchefstroom, Pietermaritzburg, Durban, Grahamstown and Stellenbosch, where he gave talks on the ancient roots of modern superstition, Vergil's view of life, the Dutch excavation of a Mithraeum underneath the Stazione Prisca in Rome (with slides), the Epicureans' and Stoics' debate with Jesus (Acts 17.18), Apuleius' tale of Amor and Psyche (with slides), Horace's Carmen Saeculare, Lucretius' dilemma, and Lucretius, Catullus, Vergil and Horace and their Dutch interpreters. $^{24}$

\subsubsection{Acta Classica}

The decision to publish the proceedings of the conference also demanded attention. The Executive Committee at first intended to print and circulate the acta in cyclostyled format, perhaps in a number of the Newsletter of the Departments of Greek and Latin at Stellenbosch University (later Akroterion). There were no funds for anything grander. ${ }^{25}$ At the same time, the Committee was debating the idea of a Festschrift for Prof. Haarhoff who had just retired. Dr Naudé had unsuccessfully approached the University of the Witwatersrand, ${ }^{26}$ and Prof. Goold then approached Blackwell's in Oxford. They were willing to publish such a volume of essays, provided the articles had a unifying theme (Latin literature), were accessible to the English-speaking public, and the association guaranteed the sum of $£ 500$. The title was to be Latin Poetry or Roman Life and Letters, and would appear under the auspices of CASA. Authors who were friends and colleagues of Haarhoff in South Africa and abroad were

20. Van Rooy circular, 8 May 1958. The questions were: (1) Do you consider that the humanities, and Latin in particular, are in fact being left behind in significance, achievement and practical value? (2) What do you consider the most significant contributions and developments made in the past 50 years? (3) What do you consider the true spiritual and practical value of Classics in modern society? (4) What growth has there been in your department? (5) To what extent have the humanities been left behind in the matter of grants, scholarships, research facilities and publication possibilities? (6) If the humanities are indeed being disadvantaged, what measures would you suggest to remedy the situation?

21. C to Synod, undated; ST to C, 3 June 1957; C to ST, 15 June 1957.

22. ST to C, 26 December 1957.

23. September 1957.

24. C to ST, 6 May 1957; ST to C, 3 June 1957; C to ST, 15 June 1957.

25. C to ST, 6 May 1957; C to ST, 15 June 1957.

26. The reason was the decision of FIEC concerning such publications (see below). 
approached and funds collected by Prof. Goold and Mr B L Hijmans in Cape Town, and Dr Naudé in Johannesburg. Subscriptions were obtained from members of CASA, and appeals for support sent to prominent persons such as His Excellency Dr Jansen, Governor-General and The Honourable Chief Justice H A Fagan, to become patrons. ${ }^{27}$

Then some difficulties arose. Although the project was endorsed by the Executive Committee, objections were raised that foreign contributors outnumbered local ones and that articles on Greek topics and those written in Afrikaans (despite the work of the honorandus in this field) were excluded. In addition, Prof. Viljoen drew attention to the strongly worded decision of FIEC in Amsterdam in 1956 against the practice of special publications to honour scholars, and for the use of particular volumes of existing periodicals or series. He proposed that the Executive Committee give urgent consideration to either (1) publish the acta of the association and dedicate the first volume to Prof. Haarhoff, or (2) publish a separate Festschrift under the auspices of the association, but only if the amount of $£ 500$ required by Blackwell's was contractually secured to cover the costs. He added that the Executive Committee should take special care to ensure the academic quality of the South African contributions. $^{28}$

Other considerations were noted: donations had already been made specifically for a Haarhoff-project, and would have to be acknowledged properly in the case of option (1) above; there was perhaps insufficient time to produce a volume of high quality in time to present it formally to Prof. Haarhoff at the next CASA conference scheduled for 1958; the members of the editorial board had to be chosen; the finances for the project had to be administered; as a first publication of CASA, it would have to reflect the proceedings of the association (the acta: foundation, meetings, constitution) and contain some of the papers delivered at conferences, in addition to the dedication to Prof. Haarhoff. ${ }^{29}$

By the end of August, the Chairperson, Prof. Smuts, expressed the need for urgency and finality, mainly because Prof. Haarhoff might already suspect something and be disappointed if the project were delayed or aborted, and the interest of donors had to be kept alive. In the interests of the association, he requested Dr Lubbe to meet with Prof. Viljoen and other colleagues in Pretoria and Johannesburg to thrash out a plan of action. ${ }^{30}$ Prof. Viljoen, Drr Lubbe, Naudé and De Kock (Pretoria) met and submitted a report dated 3 September 1957, which stated:

a) that the idea of a separate Festschrift as conceived by Prof. Goold, though praiseworthy, would be very difficult to carry out for the following reasons: (1) there could be no guarantee of $£ 500$ to Blackwell's; (2) the decision of FIEC, though not binding, could impact negatively on the publication; (3) the book could not appear within the period intended; (4) the predominance of foreign contributions and a publisher from the English-speaking world would exclude local, and particularly Afrikaans, contributions, whereas the honorandus himself had in his work propagated the fusion of Classical and Afrikaans culture;

b) that the association pursue the alternative plan, namely that the acta of the association be published as soon as possible and be dedicated to Prof. Haarhoff, with

27. ST to C, 3 June 1957; C to ST, 15 June 1957; C to EC, 2 August 1957; ST to C, 6 August 1957; C to ST, 25 August 1957.

28. C to EC, 24 August 1957.

29. C to EC, 24 August 1957.

30. C to ST, 25 August 1957. 
the following guidelines: (1) to collect voluntary financial contributions from members of CASA, donors, and the National Council for Social Research, and to acknowledge such donations in the volume; (2) to invite foreign scholars to offer their contributions for this new publication; (3) to approach a local publisher who would also be willing, as a gesture of goodwill, to quote a reduced price; (4) to forgo the appointment of patrons; (5) to appoint an Editorial Board consisting of Proff. Smuts (Chair), Viljoen (Editor and Secretary), Mr Hijmans (Assistant Secretary), Prof. Goold (in appreciation of his input and possible assistance abroad) and Dr Naudé; (6) to second the Chairperson's proposals in his circular of 25 August 1957: a clear dedication to Prof. Haarhoff, a report on the activities of CASA, an appreciation of Prof. Haarhoff by Prof. Petrie, articles by South African scholars (but not restricted to Latin as previously envisaged); (7) to set 31 December 1957 as the deadline for contributions; (8) to request the Editorial Board (a) to select articles after submission to competent referees, (b) to monitor the effect of this publication on the proposed legislation of the Minister of Justice, and (c) the number of copies to be printed, including complimentary copies for libraries abroad which should be approached to subscribe; (9) to consider dedicating the next volume of the acta of the association to Prof. Petrie.

The report was also sent to other members of the Executive Committee, Proff. White and Van Rooy.

In October Prof. Smuts informed the Executive Committee of the situation. Prof. White felt that the two publications were to be kept apart, ${ }^{31}$ while Prof. Van Rooy was in favour of the publication of the acta first, and then, if finances permitted, the Festschrift. Prof. Smuts had discussed the matter with Prof. Goold and Mr Hijmans two days before the former's departure, and obtained their agreement. The majority of members were now in agreement to go ahead with the publication of the acta dedicated to Prof. Haarhoff. Dr P L Nicolaides, an enthusiastic businessman and philhellene, had in the meantime joined Dr Naudé in the fundraising campaign, and articles had already begun arriving. ${ }^{32}$ The Secretary of the Editorial Committee, Prof. Viljoen, sent a circular to all members informing them of the final decisions and inviting contributions for the second volume of what was now to be called Acta Classica. ${ }^{33}$ The projected cost was $£ 390 .^{34}$

The first volume of Acta Classica, with the sub-title Roman Life and Letters and dedicated to Prof. Haarhoff, was published by A A Balkema of Cape Town in $1959 .^{35}$ The publication was funded by donations from private individuals (neurosurgeons, clerics, lawyers, judges, academics in Classics and other fields), businesses (booksellers), educational institutions, and Hellenic communities. ${ }^{36}$ The Editorial Board consisted of Proff. Smuts, Goold, Viljoen, Drr Naudé and P L Nicolaides, and Mr Hijmans.

31. White to ST, 26 September 1957.

32. C to EC, 9 October 1957; C to ST, 14 December 1957.

33. SEC circular, 2 April 1958.

34. SEC to ST, 6 June 1958.

35. Cf. also Editors, AClass 1 (1958a) 3-4.

36. Worth mentioning by name, in view of their subsequent careers, are Mrs Killie Campbell, Prof. Raymond Dart, and Mr Harry Oppenheimer. Cf. Editors, AClass 1 (1958a) 5. 


\subsubsection{Co-operation with CARN}

In May 1958 a request was received from Dr T F Carney (University College of Rhodesia and Nyasaland), Secretary of the newly-established Classical Association of Rhodesia and Nyasaland (CARN), proposing "the most cordial and cooperative relationship" between the two associations. A copy of the CARN constitution was circulated among members of the Executive Committee, and, in view of Dr Carney's wish to table the matter at the AGM of CARN on 19 June, the request was provisionally granted by the Acting Chairperson of CASA pending later approval. ${ }^{37}$ Prof. White also sent the following message:

Societas Classica Africae Australis Societati Classicae Rhodesianae salutem. His praesertim temporibus, amici, plurimum interest ut ei, quibus litterae humaniores cordi sunt, cum eis qui, sive in scholis, sive in collegiis, in haec studia curam operamque conferunt, amicitiae studiique communis artioribus vinclis inter se coniungantur. Gaudemus igitur, viri doctissimi, quod litterarum humaniorum fautores in Rhodesia atque in propinquis Africae Mediterraneae regionibus, in Societatem Classicam nuper congressi, nostram Societatem invitavistis ut leges atque instituta vestra rata habeamus. Quae quidem valde approbamus, Societatem vestram florere et salvere iubemus. Scripta a Foro Graemii, prid. Id. Iun. A.S. MCMLVIII. Praesidis Vicarius., 38

\subsubsection{Final matters}

In a circular to the Executive Committee in November 1958 several matters were dealt with: a proposed new letterhead with the tomb (mausoleum) of Mausolus at Halicarnassus, symbolising the appreciation of the Classical heritage in a non-Classical world; cooperation with CARN, including reciprocal membership and attendance at the conferences of the two associations; the revised conference date and programme (allowing for hour-long papers and 45-minute discussions, and a session for school teachers); affiliation with FIEC; financial support from the universities for delegates to conferences; additional regional branches in the Free State and Natal; financial matters; the publication of Acta Classica; the criteria for the various categories of membership, and the canvassing of new members. ${ }^{39}$ In Appendix 5 to

37. ST to White, 7 June 1958; White to ST, 12 June 1958; ST to White, 27 June 1958.

38. "The Classical Association of South Africa sends greetings to the Classical Association of Rhodesia. In these times especially, my friends, it is important that those who hold the humanities dear, together with those who, either in schools or in colleges, devote their care and effort to these pursuits, should be joined together by closer ties of friendship and shared interest. We therefore rejoice, learned gentlemen, that the supporters of the humanities in Rhodesia and neighbouring regions of Central Africa, recently constituted into a Classical Association, have invited our Association to ratify your laws and institutions. These we firmly approve, and bid your Association blossom and survive. Written at Grahamstown, 12 June 1958. Vice-Chairman."

39. ST to EC, 1 November 1958, with (in Afrikaans and English) Appendices 1-4 (CARN constitution, programme), 5 (affiliation with FIEC, financial support for delegates, invitation from CARN to hold the next conference in Salisbury in 1960, formation of additional regional branches), 6 (arrangements with A A Balkema to publish Acta Classica). Appendix 6 contains some interesting facts: the cost of publication of 500 copies was $£ 325$, plus $£ 50$ for cloth-bound covers for all copies and a leather-bound copy for Prof. Haarhoff; the annual subscription would be 35 shillings, of which 25 shillings would accrue to the Association and be used for the next volume; and the estimated production time was four months; cf. also Report at Meeting, 31 January 1959. Also C to ST, 22 November 1958; ST to EC, 1 December 1958; C to ST, 10 December 1958; ST to C, 18 December 1958; C to ST, 22 December 1958; C to Richards, 16 January 1958; C to ST, 16 January 1958. 
this circular Prof. Viljoen proposed that, in the light of the invitation from FIEC to send a representative to attend the Third International Conference of Classical Studies to be held in London from 31 August to 5 September 1959, one Classical scholar should be chosen to represent CASA and that all the universities should be asked to contribute towards the costs. In a personal letter to Viljoen, Prof. B A van Groningen, then President of FIEC, wrote: "Ook Zuid-Afrika hoort in deze federatie. Tot aan het eerstkomende internationale kongres van classici (volgenden zomer in London), ben ik voorsitter. Eventueel kan ik dus de nodige stappen doen. Toetreding zou kunnen geschieden op te algemene vergadering, die dan ook gehouden wordt.” The matter could be discussed and finalised at the conference of CASA. Prof. S J H Steven (University of the Orange Free State) was asked to deliver the laudatio on the occasion of the presentation of the first volume of Acta Classica to Prof. Haarhoff. ${ }^{40}$

\subsection{The Regional Branches}

The Northern Branch met in Potchefstroom on 26 October 1957. Twenty-four persons attended, ten of them school teachers. The delegates, and Prof. Haarhoff in particular, were welcomed by the Rector of the University, Prof. J C Coetzee. In reply, Haarhoff expressed his pleasure at the growing interest in classical scholarship among our classicists and their assuming their place alongside scholars in Europe. At the business meeting the new committee was elected: Dr Naudé (Chair), Dr Viljoen (Secretary), Miss S L Sellschop and Mr J C Mentz (representing the schools), Proff. S Davis (Witwatersrand), Postma, Gonin and Mr Richards (Pretoria; representing the other universities). A talk was given by Prof. Coetzee on "Die rol van Latyn in ons Middelbare onderwys", followed by a discussion. ${ }^{41}$ In a circulated report the Secretary summarised the meeting, suggested an additional conference in April, and explained the aims and activities of the Association. ${ }^{42}$

A conference was duly held on 26 April 1958 at the University of the Witwatersrand. Forty-five persons attended, of whom 18 were visitors and students. Prof. Haarhoff, who had travelled from Stellenbosch to attend, was asked to chair the conference. The Principal, Prof. Sutton, opened the conference with a short speech in which he emphasised how much, for example, modern thought owed to ancient Greek philosophy, and our legal system owed to Roman law. Our universities, he continued, sent out students without an awareness of how western civilisation had reached its level of development. Prof. Van Rooy spoke on "Oorlewering, taalwetenskap, argeologie en aspekte van die voor-Helleense beskawing in

Kreta en Griekeland”, and Prof. Davis (who had succeeded Prof. Haarhoff in the Chair of Classics) on "Linear A and Linear B: some problems." After lunch, a debate was held on "The claim of Roman history to be included in the High School Latin syllabus." In the closing session, the meeting was informed that the number of matriculates taking Latin in Transvaal schools had risen from 550 to 1 050, and the number of schools offering Latin from 45 to 77. A committee, consisting of Proff. Coetzee and Steven and Mr J T Engelbrecht, was elected to monitor the position of Latin in the schools. ${ }^{43}$

The AGM was held on Friday 22 and Saturday 23 August 1958 to coincide with the Cicero and Ovid Jubilees organised by the Latin Department of the University of Pretoria.

40. Viljoen to ST, 8 October 1958; C to Van Rooy, 14 December 1958.

41. Minutes of Meeting, 26 October 1957.

42. $\mathrm{S}$ to members, 31 January 1959.

43. S to members, 31 March 1958; Minutes of Meeting, 26 April 1958; Editors, AClass 2 (1959) 126. 
Since these authors were prescribed in school syllabi, the talks were aimed at schoolteachers and pupils: "Cicero the student" (Viljoen), "Cicero the writer" (Coetzee), "Cicero the orator" (Gonin), "Cicero the advocate" (Dr P. Rabie, local advocate), "Cicero the statesman" (Steven), and "Ovid and his influence on European literature” (Davis). Between 150 and 200 people attended one or more of the sessions, including the deans of the Faculties of Arts, Science, Law, and Economics and Administration, advocates and groups of schoolchildren. On the Saturday morning, in the presence of the Rector, Prof. C H Rautenbach, Mrs Viljoen unveiled a commemorative plaque to designate the $H G$ Viljoen Classics Reading-Room in the Merensky Library. ${ }^{44}$

At the business meeting, attended by the Honorary President, Prof. Haarhoff, and Dr Carney and Ms Philippa Forder of the University College of Rhodesia and Nyasaland, it was suggested that, as the Northern Branch covered too wide an area, the centres in the Free State and Natal should investigate the feasibility of establishing their own regional branches. The new committee was requested to organise a conference for teachers of Latin, with short talks followed by lengthy discussion, on topics such as: the aim, value and place of Latin at school; the amount of time allocated to Latin on the time-table; more variety in the selection of setworks; the correct pronunciation of Latin; the interpretation of literary texts; the method of teaching Roman history; and practical problems in the classroom. Dr Carney reported on the formation and activities of the Classical Association of Rhodesia and Nyasaland. The new committee was then elected: Prof. Gonin (Chair), Prof. Viljoen (Secretary), Messrs Mentz and Engelbrecht (Additional members). ${ }^{45}$

In Johannesburg, Prof. Haarhoff delivered his final Vergil Lecture in 1957, ${ }^{46}$ while in the Eastern Cape Prof. White reported on a meeting of local teachers, and a membership campaign, adding "this thing needs to be sold like insurance!” The members of the Classics Department at Rhodes University, Messrs A Milne and W $\mathrm{H}$ Hewitt, and Ms Lydia Baumbach, assisted. Prof. White was working on a series of radio talks for January on such themes as "Education and Justice", based on passages from Greek authors in translation. ${ }^{47}$ Also of interest in the light of later developments was a suggestion by a Mrs Finlay of Bloemfontein that correspondence courses in Latin should be offered by CASA. ${ }^{48}$

44. On Prof. H G Viljoen, see De Kock (1987); Editors, AClass 2 (1959) 126.

45. S to members, 25 July 1958; Gonin general invitation, August 1958; Minutes of Meeting, 15 October 1958; Editors, AClass 2 (1959) 126. In his report, Carney mentioned the successful conference in May attended by 112 schoolchildren, the monthly meetings in Salisbury attended by 60 persons, the Oliver Newton Scholarship available for students to do post-graduate study at South African universities, and the publication of the Proceedings of the African Classical Associations. He then invited CASA to hold a combined conference in Salisbury in 1960. The invitation was referred to the next conference of CASA in January 1959; ST to Carney, 3 December 1958; Carney to Van Rooy, undated. Cf. above, 3.2.4.

46. For other papers delivered at meetings of the Johannesburg Classical Association, see Editors, AClass 1 (1958b) 168.

47. White to ST, 26 September 1957.

48. C to ST, 15 June 1957; Minutes of Closing Meeting, 31 January 1959, item 14. 


\section{Third CASA conference, 28-31 January 1959, Bloemfontein}

\subsection{Conference proceedings}

The Executive Committee met before the main meetings to finalise the agendas and programme, a procedure still practised. ${ }^{49}$ The Opening Meeting started at 15:00 with 22 delegates present. Among the matters dealt with were the reports of the sub-committees (Acta Classica, the catalogue of relevant works in libraries, the spelling of Greek proper nouns in Afrikaans), finalising the letterhead, and appreciation for the Newsletter/Nuusbrief, published by the Departments of Greek and Latin at Stellenbosch. ${ }^{50}$ The tabled report of the Editorial Committee of Acta Classica detailed the process that had led to the publication of the journal: the amalgamation of the two projects, the Festschrift for Haarhoff and the publication of conference papers; the financing from donors; the contributions from local and overseas scholars; the publication by Balkema; and the sale price of 35 shillings. Planning for the second volume was approved and procedures laid down. ${ }^{51}$

On the Wednesday evening, 28 January, Prof. Smuts delivered the first Chairperson's Address. The following matters were mentioned: the value of Wagenvoort's visit; the retirement of Prof. Haarhoff and the dedication of the Acta to him; the need to promote interest in the Classics beyond the circle of classicists; the bimillenial commemoration of the death of Caesar and Cicero and of the birth of Ovid, which were to receive coverage in the press and on radio (Proff. Haarhoff and White); negotiations with the education authorities concerning the teaching of Classics, and especially Greek, in schools; the growth of departments of Greek and Latin at South African universities; the associations membership which had doubled to 90; activities of the regional branches; the important role of the Newsletter; the task of the Classicist in SA; and research. ${ }^{52}$ This was followed by the presentation of the first volume of Acta Classica to Prof. Haarhoff. Prof. Steven read the following Laudatio: ${ }^{53}$ T J Haarhoff, BA (Cape), B. Litt. (Oxon.), Litt. D. (Amsterdam), Professor Emeritus of
University of the Witwatersrand, Johannesburg.

Theodore Johannes Haarhoff: Paneygyricus Sermo

Of all modern scholars, Theodore Johannes Haarhoff would perhaps have least wished that an encomium be spoken on him in his presence. It is fitting, however, that on this occasion, when the first number of our Acta Classica is being officially dedicated to him - Plato, Rep.

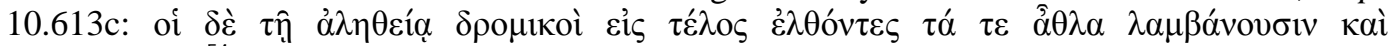
$\sigma \tau \varepsilon \varphi \alpha v o v v \tau \alpha^{54}$ — it is fitting, I say, that a few words be said - alas! Only a very imperfect indication of the very great honour and esteem, in which every single one of us holds a man qui

49. Agenda, 28 and 30 January 1959; Minutes (in English and Afrikaans), 28 and 30 January 1959.

50. Minutes of Opening Meeting, 28 January 1959; Editors, AClass 2 (1959) 128-130. Invitations to the Bishop of Bloemfontein, Director of Education, Mayor of Bloemfontein, Chief Inspector of Schools, Editor of The Friend newspaper were all declined with excuses of prior engagements: letters dated 23, 24 and 26 January 1959.

51. Report of Editorial Committee. The sum raised was $£ 412$.

52. ST to C, 13 January 1958.

53. Manuscript of the Steven speech (with asides here included in square brackets); typescript of the Haarhoff speech with corrections in his own hand; Short Report of conference (in English and Afrikaans, and drafts).

54. "The real runners, who run to the end, receive the prize and are crowned." 
nullum fere scribendi genus non tetigit. ${ }^{55}$ As befits the classical scholar that Haarhoff is, I should have spoken this encomium in Latin and followed in the example of Dr Johnson, who, when he was asked to write an epitaph - absit omen ${ }^{56}$ — on Goldsmith in English, refused to do so, saying he would never consent to disgrace the walls of Westminster Abbey with an English inscription. But, alas! In the $20^{\text {th }}$ century Latin demands translation and Haarhoff himself, I think, would acquiesce; he who more than any other in our country has striven to convey the classical message in the vernacular.

Haarhoff, like the late John Ross, was a product of the old Cape system of education with its strong emphasis on the Classics as a guide to life and like his great contemporary and friend, the humanitas of the ancient world was ever to serve as his palladium and, I may add, solace amid many cares (in malis ferventibus). As I write, I think of Mathew Arnold's words:

Backward and forward rolled the waves of fight

Round Troy; but while this stood, Troy could not fall.

At Oxford, where Haarhoff went as Rhodes Scholar, he soon made his mark and his Schools of Gaul. A Study of Pagan and Christian Education in the Last Century of the Western Empire (a second edition has recently been issued by the Witwatersrand University Press, 1958) is a memorable monument of his stay there. I did not know him there - and first met him when he was a young lecturer at Cape Town University, curiously enough on the hockey-field, a game which he had flirted with in his youth.

In July 1925 I went up to Wits to substitute for him for six months to enable him to take one of his trips overseas, where he was to do so much to put classical South Africa on the map and where he was later to complete his masterly doctoral thesis, which he wrote round the two great passions in his life - Vergil and South Africa. For many years he continued teaching at the University, punctuating his stay there with publications, the fruit of his learning and experience of life. Donatus iam rude ${ }^{57}$ by his old University — our pension laws are rigorous - he still continues his teaching to the great joy and profit of his pupils in the Mother-City. It is our fervent wish that he will be spared for some time still to continue with this noble task (words of Abbé of Fleury: "nihil in vita iucundius quam discere aut docere"). ${ }^{58}$

I have no intention of mentioning all his publications by name - each in its turn was to make not a small impression on the learned world and on me in particular. From Haarhoff I have learned not a little. I shall never forget the parallel he was to draw between the virtues of the early Latin farmer and the Voortrekker - between the anima naturaliter stoica and the anima naturaliter Calviniana ${ }^{59}$ and the impact that his point of view made on me at the time. His sense of humour - a genuine child of humanitas - shines through all his writings, impregnating them with gentleness, which is so loathe to hurt. Always I shall remember the glint in his eye, when he spoke of schoolboy howlers and mentioned two in particular, which appealed to him - you surely remember them - Ave, domine! and Ambo Felices ${ }^{60}$ (surely in this emulating Giraldus Cambrensis [end of the 12th century] who tells of a certain abbot's incapacity to translate the simplest passages from the Bible or the Missal. He rendered the first words of the Mass Preface: "aequum et salutare", viz. "right and available to salvation" as "the horse jumped" - i.e., equus saltavit). One remembers those words of his also, I quote: "After some

55. "Who set his hand to almost every kind of writing."

56. "Perish the thought!"

57. "Given the (gladiator's) staff” (Hor. Epi. 1.1.2) as a sign of honourable discharge.

58. "Nothing in life is more pleasant than to learn or to teach."

59. "Soul naturally Stoic", "soul naturally Calvinistic.”

60 . The point of the howlers is not explained in the written text of the speech. 
years of Matriculation-examining I have come to the profound conclusion that Caesar was a book.”

His publications written in impeccable English and Afrikaans reveal the "fullness", the "holism" of his way of life, so much in consonance with that of his great friends, the late Gen. J C Smuts and Mr J H Hofmeyr. Haarhoff is en bly 'n seun van ons land - sy politieke ideaal 'n verenigde volk waar Afrikaner en Engelsman, Duitser en Fransman, bereid sal wees om mekaar die hand te gee en om saam te werk vir die belange en voorspoed van ons land Suid-Afrika.

Die humanitas van die Antieke Wêreld - hy is besonder lief om die volgende reël uit Terentius aan te haal, nl. homo sum; humani nil a me alienum puto ("Ek is 'n mens; niks mensliks ag ek my vreemd nie") — die humanitas bly vir hom die middel par excellence om nader aan hierdie ideaal van samewerking te kom — die concordia ordinum van Cicero, nl. "'n mobilisasie van gematigdheid”. Soos Cicero sal hy ook die immortalitas gloriae bereik optimi cuiusque animus maxime ad immortalitatem gloriae nitens. ${ }^{61}$

Dit is en bly 'n verhewe ideaal wat elkeen van ons, wat vaderlandsliewend is, sal kan onderskryf. Haarhoff se vertalings uit die Grieks en Latyn het die vooroordeel, wat daar in 'n betreklike jong land soos ons s'n wel bestaan teen die Griekse en die Romeinse beskawings, aansienlik verminder - en ek dink ook aan diegene van ons burgers, wat nooit die geleentheid gehad het om Grieks en Latyn op skool te leer nie, maar wat belangstel in die leerstellinge en lewensfilosofie van die Antieke Wêreld en wat begerig is om daarmee nader kennis te maak vir hulle is Haarhoff se vertalings werklik 'n reddingsgordel.

Ek dink bv. aan iets wat Haarhoff self my op 'n dag vertel het dat 'n Karoo-boer aan hom gesê het dat hy Die Romeinse Boer - qua quid potest esse tum fructu laetius tum adspectu pulchrius? ${ }^{62}$ die beste handboek oor die boerdery wat hy nog ooit gelees het, beskou het en dat hy streng volgens die leer van daardie vertaling boer, nog steeds met eksellente gevolge. Het die ou-Romeine moskonfyt (Lat. defrutum; mustum confectum) gemaak? Dan dink ek veral aan Hoe Troje geval het - Aeneïs II — met begeestering deur Haarhoff vertaal — dit verskyn in sy Die Kortverhaal van die Grieke en Romeine. Veroorloof my om enkele reëls daaruit aan te haal:

"Só was die end van Priamus se lot: só die dood wat hom beskore was - om Troje in vlamme te sien en haar Burg 'n puinhoop - hy wat eens hoogmoedig geregeer het oor so baie rasse en landstreke, 'n koning van Klein-Asië. Daar lê hy, 'n magtige liggaam op die strand, die hoof van die skouers geskeur, 'n naamlose lyk."

Hierdie vertaling ontroer my persoonlik besonder.

Haarhoff se werkywer was eenvoudig reusagtig. Afgesien van sy substantiewe werke, het daar tallose publikasies (artikels) van sy pen verskyn. Ek dink bv. aan 'n referaat deur Haarhoff gelewer aan die Virgil Society te Londen op 28 April 1956 - "Virgil, prophet of peace with some reference to Dante” — wat op die Engelse geleerdes en op my persoonlik 'n groot indruk gemaak het. Veroorloof my om enkele reëls hieruit aan te haal (bl. 11):

"Yet when we consider Vergil's feeling for animals — he loved the small animals like St Francis - his delight in flowers and his view of Nature as an expression of the Divine, capable of bringing peace to human hearts; ... his sympathy with the lot of mankind and

61. "... the souls of our finest men striving especially for the immortality of fame" (adapted from Cic. De sen. 23.82).

62. "What can be both more pleasing in its fruit and beautiful in its appearance than this?" (Cic. De sen. 15.53, speaking about the vine). 
the innocent victims even of the enemy ... his ideal of service ... we cannot surely deny him the virtue of Christian Caritas.”

And then those magnificent, almost self-revealing lines at the end of the lecture on p. 16:

"only he who has known the darkness of the Inferno and climbed the toilsome Mountain of Purification, can understand fully the inner peace symbolized by that smile (il santo riso, the sacred smile of Beatrice) and share the true vision of the Vergilian ivory gate.”

Soos ou Cato, mag Haarhoff wel sê: "Hae sunt exercitationes ingenii, haec curricula mentis: in his desudans atque elaborans corporis vires non magno opere desidero." 63

Maar die tyd vang my. Tempora labuntur. Quem novere omnes, testimonio non eget. Qua re finem faciam. Te saluto, Haarhoff, poetam, doctum virum et Graecis litteris eruditum, concordiae et amicitiae fautorem, amoenitatis artiumque optimarum amatorem, ingenio sublimem, vividum, versatilem, nitidum, venustum. Ut apud Claudianum legimus, "Dis

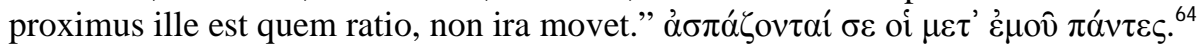

The encomium was greeted with acclamation. In reply, Haarhoff delivered the following Oratio Latina:

Praeses Praeclare, Collegae atque Amici, sollemne erat apud Romanos antiquos virum singularem pro rostris laudare, sed non nisi mortuum. In charta vestra rerum agendarum nobis, humanitatis fautoribus, video amicum meum, Stevenium, virum doctissimum, laudatorem appellatum esse. Spero tamen, collegae mei, vos me nondum animo meo iam mortuum esse et rude donandum opinari; quod ad me attinet, studio de novo accenso, sentio vestram vividam vim animi et labores ingentes scribae nostri, Lubbii, quem nomino honoris causa, maximo cum gaudio.

Mihi contemplanti hos triginta annos videor persaepe docendo aravisse deserta locorum, ut dixit aliquando clarissimus Alexander Petreius noster, vir tam pietate quam doctrina insignis, Nestor sane noster sapientissimus. Sed sementem feci quantum poteram et fortasse semina quaedam in fructus tandem efflorescent. Hoc tamen sine dubio et laeto animo affirmare possum, iuniores inter doctos classicos nostros vigore praestanti causam nostram promovisse; et ut illud Lucretianum recorder

quasi cursores vitai lampada tradunt.

Quare amici, vehementer commotus animo, pro laboribus tantis, pro summo hoc honore, pro libro doctissimo, gratias ago maximas. Vincula doctrinae atque amicitiae inter nos sane astringenda sunt; et est mihi pergratum quod homines humanitatis studiosos tam praeclaros, trans oceanum dissociabilem invenistis qui testimonia sua darent. Eis quidem qui magna impensa, liberalissimo animo, hunc librum in lucem protulerunt, inter quos praecipue nomino Philippum Nicolaidem, quasi Atticum nostrum, virum et ipsum doctissimum, virum, si quis, litterarum humaniorum adiutorem, maximas ago gratias. Professores singuli transeunt: sed, ut ait Vergilius verbis paulum mutatis de apibus

63. "These are the exercises of my intellect, these the race-tracks of my mind: sweating and toiling at them I do not greatly miss my bodily strength” (Cic. De sen. 11.38).

64. "Time moves on. He, whom all knows, does not need a testimonial. Therefore, I shall end. I salute you, Haarhoff, poet, scholar and expert on Greek literature, promoter of harmony and friendship, lover of beauty and the finest arts, elevated in intellect, lively, versatile, elegant, charming. As we read in Claudian: 'He whom reason and not anger moves, is closest to the gods.' All with me salute you.” 
ergo ipsas quamvis angusti terminus aevi

excipiat...

at genus immortale manet, multosque per annos

stat fortuna domus.

Stet fortuna domus classicae nostrae! Semper adsint qui vitai lampada tradant! Floreat, vivat, in hoc tam barbaro mundo societas nostra classica Africae Australis. Quod felix faustum fortunatum vortat! ${ }^{65}$

A further eleven papers were read, and one talk with slides given. ${ }^{66}$

At the Closing Meeting on 31 January 1959, the following were among the matters dealt with: the Museum Committee was to proceed with the assistance of the education authorities; the Editorial Board for Acta Classica was to consist of Prof. Viljoen (Editor), Dr Naudé (Treasurer), with the collaboration of Proff. Gonin, White, Van Rooy, Coetzee, and Drs Nicolaides, Carney and Hijmans; the invitation by CARN was gratefully acknowledged, but the proposed combined conference was to be a special occasion, outside the Association's normal programme, at least 15 delegates from South Africa would be required to make the project viable, and the views of CASA members would be canvassed; the Executive was to investigate affiliation with FIEC, due to meet in London from 31 August to 5 September 1959, and to nominate as the CASA representative a South African classicist who happened to be abroad at the time; the holding of conferences on a biennial basis was confirmed; Prof. Rollo was elected Honorary President alongside Haarhoff and Petrie; ${ }^{67}$ and the new

65. "Distinguished Chairman, colleagues and friends, it was customary among the ancient Romans to praise a distinguished man in front of the rostra, but not unless he was dead. On your programme of items to be dealt with by you, supporters of the Classics, I see that my friend Stephen, most learned man, has been named as eulogist. However I hope, colleagues, you do not yet regard me as already dead and to be discharged. As far as I am concerned, with interest kindled anew, I feel your lively force of mind and the great toils of our secretary Lubbe, whom I name out of respect, with the greatest of pleasure.

As I contemplate the past 30 years, I seem very often in my teaching to have ploughed deserts, as our most distinguished friend Alexander Petrie once said, a man outstanding in both loyalty and learning, clearly our own most wise Nestor. But I played the part of sower as best I could and perhaps some seed will at last flower into fruit. This, however, I can without doubt and with happy heart state, that the younger ones among our Classical scholars have promoted our cause with exceptional vigour; and to recall that saying of Lucretius:

like runners they hand over life's torches

Therefore, my friends, strongly moved in spirit, I thank you very much for such great efforts, for this most high honour, for this most learned book. The ties of learning and friendship between us must surely be drawn tight; and it is very gratifying for me that you have found such famous Classical scholars from overseas to give their testimony. To those who with great dedication, most liberal mind, have produced this book - among whom I mention in particular Philip Nicolaides, our Atticus so to speak, he too a most learned man, if ever there was, promoter of Classics - I offer the greatest thanks. Individual professors pass on; but, as Vergil says about bees, with the words changed a little:

thus, although the end of a narrow life takes them off as individuals . . .

yet their kind remains immortal, and over many years

the fortune of their home stands (Verg. Geor. 4.206-09).

May the fortune of our classical home stand! May there always be those who hand over life's torches! May our Classical Association of South Africa flourish and live on in this so uncivilised world. And may it turn out happy, prosperous and fortunate.”

66. For a list of the papers read, cf. Editors, AClass 2 (1959) 126-28.

67. Letter of confirmation from ST, 3 March 1959; letter of acceptance and thanks, Rollo to ST, 10 March 1959. 
Executive Committee was to be Prof. Smuts (Chair), Prof. White (Vice-Chair), Dr De Kock (Secretary-Treasurer), Prof. Gonin (Assistant Secretary-Treasurer), Prof. Van Rooy (Additional Member). The Constitution was revised and approved. ${ }^{68}$

\subsection{Administration 1959-1961}

\subsubsection{General}

The decision regarding the combined conference in Salisbury was communicated to Dr Carney. ${ }^{69}$ In a letter that crossed this communication, Carney, writing from a country in a state of emergency, informed the CASA Executive that the Academic Board of his university had approved the proposed conference; he then made suggestions regarding dates, topics, a conference for schools after the combined conference, accommodation, and fees paid for lectures at the schools' conference (3 guineas each), and offered his congratulations on the first volume of Acta Classica. ${ }^{70}$ A circular was sent to members announcing the dates (27-29 January 1960) and arrangements of the proposed combined conference, and requesting an attached questionnaire to be completed and returned. ${ }^{71}$ In the event, the combined conference did not materialise: only nine persons were able to attend, and the AGM had set a minimum of $15 .^{72}$

The Chairperson seconded a suggestion by the Secretary-Treasurer that a filing cabinet be obtained to store the archives of the Association. ${ }^{73}$ This decision led to the preservation of the Association's documents.

The Executive received an invitation from the Secretary of FIEC, Mlle Juliette Ernst, to send an observer to the Assemblée Générale in London on 29-30 August 1959, since CASA was not yet affiliated to the international organisation. Dr Nicolaides, who was to attend the conference in his private capacity, and Mr J J Coetzee (Potchefstroom University), who was on study leave in London, were nominated. ${ }^{74}$

Although not a CASA project, but one involving South African classicists, mention should be made of the special edition of Lantern (9.1, September 1959) devoted to Greece and Rome. $^{75}$ The editor, Mr V C Wood, had asked Prof. Haarhoff to provide the contributions (in either English or Afrikaans). ${ }^{76}$

At a special meeting of the Executive in Pretoria on 2 February 1960, outstanding matters emanating from AGM decisions were dealt with. These included the proposed leaflet for enrolment of members, the organisation of the Regional Branches in Natal, the museumexchange programme, a new letterhead, the use of printed accounts for subscriptions, affiliation with FIEC, objections to the proposed bill to abolish Latin for attorneys,

68. Minutes of Closing Meeting, 31 January 1959; for the Minutes and Constitution, see Editors, AClass 2 (1959) 126-130; 130-33 (English and Afrikaans).

69. S. to Carney, 3 March 1959.

70. Carney to Viljoen, 7 March 1959.

71. ST to members, 20 June 1960 (in English and Afrikaans).

72. ST to C, 24 August 1959.

73. C to ST, 4 May 1959.

74. C to ST, 20 August, 1959; C to Nicolaides, 20 August 1959; ST to C, 24 August 1959; Editors, AClass 4 (1961) $120-21$.

75. This cultural journal was published under the patronage of the Department of Education, Arts and Science by the SA Association for the Advancement of Knowledge and Culture in Pretoria.

76. C to Wood, 16 September 1959; “Editorial”, Lantern 9.1 (1959) 3. 
representations to the Sinodal Commissions regarding the desirability of Latin for propaedeutic studies, the subsidisation of Acta Classica from central funds, the venue and dates of the next conference, the transference of the Association's funds from a Post Office savings account to a savings account with the National Building Society, with signing-rights vested in the Secretary-Treasurer and one other executive member. ${ }^{77}$

Two particular items highlight the problems faced by committee members before the time of the Xerox machine, computer or e-mail. The old official letterheads were depleted and printing more with the names of the Executive for the remainder of their term of office would involve unnecessary expense. So it was decided to print more without the icon and names, and simply add the necessary details with a rubber stamp. Then, the meeting was held without informing the Vice-Chairperson, Prof. White. The Secretary-Treasurer wrote a letter offering an apology and an explanation. The Chairperson, Prof. Smuts, was also Chairperson of the Hygiene Committee of the Stellenbosch Municipality, which had decided to modernise their abattoir. An air ticket was provided for Prof. Smuts to inspect model abattoirs, including the one in Pretoria. He used the opportunity to call the special meeting. ${ }^{78}$

\subsubsection{Next conference}

The venue of the next conference was finalised: an official invitation came from Rhodes University. ${ }^{79}$ Soon arrangements were under way. ${ }^{80}$ In July, the Secretary-Treasurer submitted information regarding CASA conferences to the Director of Education in the Transvaal for the granting of leave to teachers to attend conferences. ${ }^{81}$ The request was not granted. $^{82}$

Prof. Van Rooy proposed that the Executive seriously consider the possibility of having a central conference theme as in the case of conferences abroad, while still allowing for papers on other topics. As motivation he pointed out the fragmented nature of the content of previous conferences; that a central theme on genre, or the rise of the individual, or the influence of Hellenism would promote a more cohesive treatment of material and thus be more beneficial for delegates; that there would be an opportunity for inter-university cooperation; and that discussion would be stimulated. The theme should accommodate Grecists and Latinists, and be determined at the AGM for the next conference. ${ }^{83}$ Some members of the Executive felt the scheme would be impracticable, especially in view of the small numbers of scholars presenting papers at conferences. The matter would be taken to the AGM. ${ }^{84}$

Other matters raised were the dedication of the third volume of Acta Classica to Prof. Rollo; and the submission of the name of Prof. Van Groningen (Leiden) to the Genootskap Nederland-Suid-Afrika, the cultural accord between the two countries, for an invitation to

77. Minutes, 3 February 1960 (in English and Afrikaans).

78. ST to White, 3 February 1960.

79. C to ST, 20 March 1960.

80. Baumbach to ST, 5 May 1960; ST to C, 23 July 1960; to Van Rooy and to White, 25 July 1960, C to ST, 15 August 1960; Van Rooy to ST, 30 August 1960 (progress report, arrangements, dates, draft programme); ST to Baumbach, 13 September 1960; ST to White, 13 September 1960; Baumbach to ST, 23 September 1960 (date); C to ST, 15 October 1960; Baumbach to ST, 17 January 1961.

81. ST, 23 July 1960.

82. Director of Education to ST, 19 August 1960.

83. Van Rooy to ST, 30 August 1960.

84. ST to White, 13 September 1960; White to ST, 26 September 1960; ST to C, 14 September 1960. 
visit South Africa. ${ }^{85}$ A formal request was submitted, highlighting the eminent Dutch scholar's status as a Classical scholar and Chairperson of the Koninklike Nederlandse Akademie van Wetenskappe, his ability as a speaker, his contribution to papyrology, his publications, and his kindly disposition to South Africa. ${ }^{86}$

\subsubsection{Acta Classica}

The second volume of the journal, dedicated to Prof. Petrie, was handed to the printers in July 1959. ${ }^{87}$ The Chairperson suggested to Prof. White that the proposed Teachers' Conference at Pietermartizburg on 21 May 1960 would be an appropriate occasion to present the volume to Prof. Petrie. $^{88}$

\subsection{The Regional Branches}

The Northern Branch held a Conference of Transvaal Latin Teachers on 25 April 1959 at the University of Pretoria. The Committee consisted of Prof. Gonin (Chair), Prof. Viljoen (Secretary) and Messrs Mentz and Engelbrecht (Additional members). Eighty teachers, lecturers, students and pupils attended. In the opening address, $\mathrm{Mr} \mathrm{H}$ A Whitecross (Inspector of Education) sketched the decline of Latin's position at school, and pleaded for a five-year course, more reading of long passages of Latin, interesting study material, properly qualified teachers, and closer contact between school and university. ${ }^{89}$ There followed a discussion on "What is our aim with the teaching of Latin at school?" introduced by Mr W J H Wilson (King Edward VII High). He argued for less emphasis on prose composition and more on the ability to read and understand a wide selection of Latin authors, and, using translations of Latin texts, on the Graeco-Roman cultural heritage. Mr J J A de Villiers (E P Bauman School) introduced a discussion of the new Latin syllabus, which placed the main emphasis on reading, a sound balance with formal grammar, a knowledge of history and culture, and the ability to read Latin correctly. Prof. Gonin spoke on "The correct pronunciation and the reading aloud of Latin", in the light of the aim of a uniform pronunciation expressed at the conference for Living Latin at Avignon in September 1956. He stated that the correct accent and vowel quantity should be taught from the beginning and with each new word, and that translation and elucidation of a passage should be followed by reading aloud in the class. Miss H A Holtzhausen (Afrikaanse Hoër Meisieskool) introduced the debate on "The method of the literary interpretation of Latin texts". She stressed background information (e.g. mythology), a thorough knowledge of the vocabulary, meaning and content of a passage, appeal to the aesthetic sense and imagination of the adolescent, and the particular characteristics of individual authors. The conference ended with a session in which delegates were given the opportunity to state points of view of interest to the teaching of Latin. ${ }^{90}$

85. C to ST, 15 October 1960.

86. ST to Genootskap Nederland-Suid-Afrika, 30 November 1960.

87. Editor to Van Rooy, 23 July 1959.

88. C to White, 8 May 1960.

89. The following statistics were supplied: from 1950-1959, the number of candidates offering Latin as a subject for the Transvaal Secondary School Certificate examination rose from 581 to 1 172, although the percentage of Latin candidates dropped from $20,6 \%$ to $15,9 \%$ of the total number of candidates.

90. Circular to members; Report of conference, with full texts of lectures and discussion; Editors, AClass 4 (1961) 116-117. 
At the AGM on 24 October 1959, held at the University of Pretoria, papers were read on the Greek mystery cults (Dr E Holm), Cicero (Messrs D B Saddington and Hewitt) and Livy (Prof. Carney). The new Committee for 1960 was elected: Prof. Davis (Chair), Prof. Viljoen (Secretary), Miss Holtzhausen and Mr C A M de Vleeschauwer (Additional members). ${ }^{91}$

A Bloemfontein branch of the Association was established on 23 October 1959. Only thirteen persons attended the meeting, but there was no lack of enthusiasm among those present. Talks were given on the problems of teaching Latin syntax (Miss Van den Heever and Prof. Steven) and slides on Rome and Italy shown (Prof. Van Rooy). The following committee was elected: Mr J W Malan (Chairperson), Prof. Steven (Vice-Chairperson), Mr Richards (Secretary) and Mrs J Pansegrouw (Additional member). ${ }^{92}$ At the second meeting, on 29 October 1960, the audience of thirteen was entertained and inspired by the enthusiastic veteran Latin teacher, Mr Malan, who gave an account of why he found the teaching of Latin "such a gloriously interesting thing”. Prof. Steven again talked on difficult syntax. The new committee for 1961 was elected: Prof. Steven (Chair), Mr A Hayden (Vice-Chair), Mr Albertse (Secretary) and Mrs Pansegrouw (Additional member). ${ }^{93}$

Prof. White organised a conference of teachers of Latin in Natal, on 21 May 1960 at the University of Natal (Pietermaritzburg), during which volume 2 of Acta Classica was formally handed over to its dedicatee, Prof. Petrie, by Mr B H P Farrer. ${ }^{94}$

On 14 October 1960 the Eastern Cape branch was launched at Grahamstown. The meeting, presided over by the Mayor of Grahamstown, was attended by 40 persons. A seriously ill Prof. Rollo spoke on the value of the Classics and Ms Baumbach on the aims and function of the Classical Association. ${ }^{95}$

\section{BIBLIOGRAPHY}

De Kock, E L 1987. Entry on H G Viljoen (in Afrikaans). In Beyers, C J \& Basson, J L (eds), SuidAfrikaanse Biografiese Woordeboek. Part V, 895-896. Pretoria: Raad vir Geesteswetenskaplike Navorsing.

Editors, 1958a. Editorial. AClass 1:3-4.

Editors, 1958b. A report on the Classical Assocciation of South Africa, 1956-1957 (in English with Afrikaans en face). AClass 1:164-69.

Editors, 1958c. Constitution of the Classical Association of South Africa (in English and Afrikaans). AClass 1:170-73.

Editors, 1959. Report on the Classical Association of South Africa, 1957-Jan. 1959 (in English and Afrikaans). AClass 2:126-133.

Editors, 1961. Report on the Classical Association of South Africa, February 1959-February 1961 (in English and Afrikaans). AClass 4:116-123.

Henderson, W J 1986. Bibliographia Classica Austro-Africana. Monumenta Afro-Hellenica no. 3. Johannesburg: Institute for Afro-Hellenic Studies.

Henderson, W J 1989. South Africa. Greek and Latin philology. In Arrighetti, G et al. (eds), La filologia greca e latina nel secolo XX, Vol. 2, 823-851. Rome: Consiglio Italiano delle Ricerche.

91. Cf. further Editors, AClass 4 (1961) 116-117.

92. Albertse to ST, 27 September 1960; Editors, AClass 4 (1961) 116-117.

93. Albertse to ST, 30 January 1961.

94. Editors, AClass 4 (1961) 116-117.

95. Prof. Rollo had taught Classics at the University of Cape Town until his retirement, and had then been appointed as the first principal of the University College of Rhodesia and Nyasaland. He was near the end of a two-year period of teaching at Rhodes University when he died on 20 October 1960. Baumbach to ST, 23 October 1960; Editors, AClass 4 (1961) 116-117, 118-119. 
Henderson, W J 1995. Bibliography of Greek and Latin Studies in South Africa 1985-1994. Monumenta Afro-Hellenica no. 4. Johannesburg: Institute for Afro-Hellenic Studies. Matier, K O 1986. De studiis Latinis in Africa Australi anglice scriptis. In Dilke, O \& Townend, G (eds), Britannia Latina. Acta omnium gentium ac nationum conventus sexti Latinis litteris linguaeque fovendis August 5-10, 1985 in Durham, 175-179. Newcastle-on-Tyne: Kendal Wilson. Matier, K O 1988. Classical Studies in South Africa. CUCD 17:41-43.

Smuts, F 1960. Classical scholarship and the teaching of Classics at Cape Town and Stellenbosch. AClass 3:7-31.

Smuts, F 1966. Die Klassieke op Stellenbosch. Newsletter 11(3):10-53, 87.

Smuts, F 1976. Die Klassieke in Suid-Afrika 1930-1976. Akroterion 21(4):11-21. 